\title{
Pharmacogenomics Findings Domain
}

National Cancer Institute

\section{Source}

National Cancer Institute. Pharmacogenomics Findings Domain. NCI Thesaurus. Code C111289.

A findings domain for gene expression and genetic variation assessments. 